Miami Nature Biotechnology Short Reports

TheScientificWorld (2001) 1(S3), 32SR

ISSN 1532-2246; DOI 10.1100/tsw.2001.152

\title{
IDENTIFICATION OF ANTIAPOPTOTIC PROTEIN KINASES AND PHOSPHATASES BY A FUNCTIONAL GENOMICS APPROACH
}

\author{
Reimar Abraham*, Daniel Schubart ${ }^{+}$, and Axel Ullrich \\ Department of Molecular Biology, Max-Planck-Institut für Biochemie, Martinsried, Germany; \\ ${ }^{+}$Axxima Pharmaceuticals, Martinsried, Germany \\ abraham@biochem.mpg.de
}

INTRODUCTION. A lot of information has been gathered about the execution apparatus of apoptosis (1). But data on signals that control the initiation of apoptosis have only recently begun to be accumulated (2). In order to identify genes that regulate the process of apoptosis upstream of the apoptosis machinery we investigated the expression of signal transduction related molecules - mainly protein kinases and phosphatases - in Hela S3 cell lines that differ in their sensitivity towards apoptosis.

METHODS. Hela S3 cells were selected for survival after treatment with an apoptosisinducing factor. Subsequently, the resistant cell clones were analyzed with respect to changes in their gene expression pattern.

RESULTS. The surviving clones were more resistant towards apoptosis than Hela S3. Analysis of the expression level of signal transduction related molecules revealed over 100 genes that are at least 2-fold upregulated in the clones when compared to Hela S3. Among the upregulated genes are well known antiapoptotic enzymes as well as enzymes that have not been linked to apoptosis before and need to be validated further.

Known antiapoptotic enzymes are for instance receptor tyrosine kinases like the EGF-receptor, HER-2 and the PDGF-receptor and tyrosine kinases like ryk. Inhibition of upregulated enzymes in the clones conferred an increased sensitivity to apoptosis proving that the upregulation indeed was responsible for the decreased apoptosis sensitivity.

Aside from known antiapoptotic proteins some proteins that are known to induce apoptosis are also upregulated suggesting that the interplay between apoptotic and antiapoptotic proteins determines the degree to which the cells are sensitive to apoptosis. These enzymes include for instance DAP-kinase, a serine threonine kinase that transmits apoptotic signals elicited by Fas (4) or csk, a tyrosine kinase that downregulates the activity of src-family kinases, which can act antiapoptotically.

Clustering of the expression data by a hierarchicalclustering method (3) found distinct clusters with proteins that could potentially upregulate and downregulate a common pathway. That corroborates the above notion of antiapoptotic and proapoptotic genes being regulated together. 


\section{REFERENCES.}

1. Hengartner, M.O. (2000) Nature 407, 770-776

2. $\quad$ Rich, T., Allen, R.L., and Wyllie, A.H. (2000) Nature 407, 777-783

3. Eisen, M.B., Spellman, P.T., Brown, P.O., and Botstein, D. (1998) Proc. Natl. Acad. Sci. U S A 95, 14863-14868

4. Cohen, O., Inbal, B., Kissil, J.L., Raveh, T., Berissi, H., Spivak-Kroizaman, T., Feinstein, E. and Kimchi, A. (1999) J. Cell Biol. 146, 141-148 

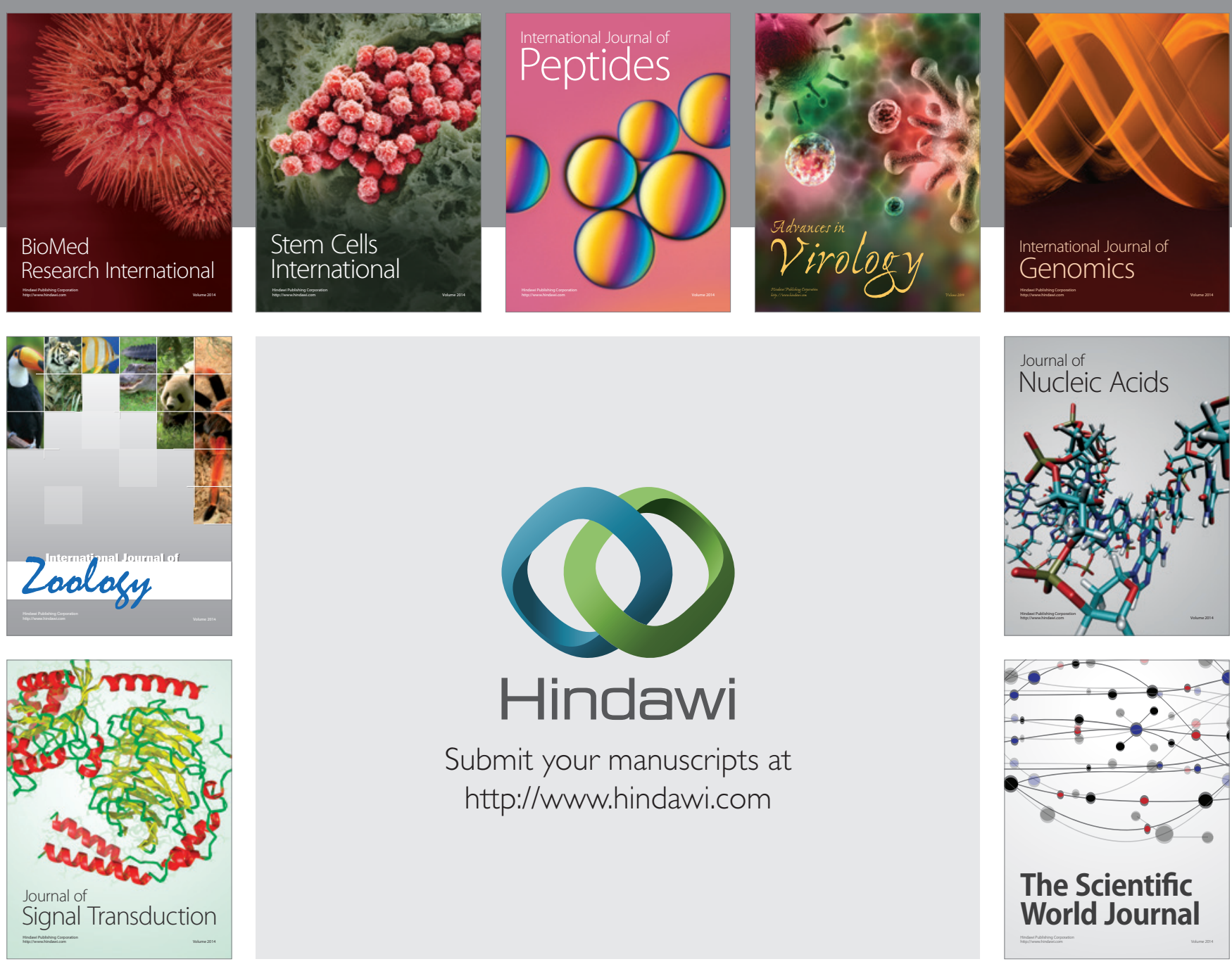

Submit your manuscripts at

http://www.hindawi.com
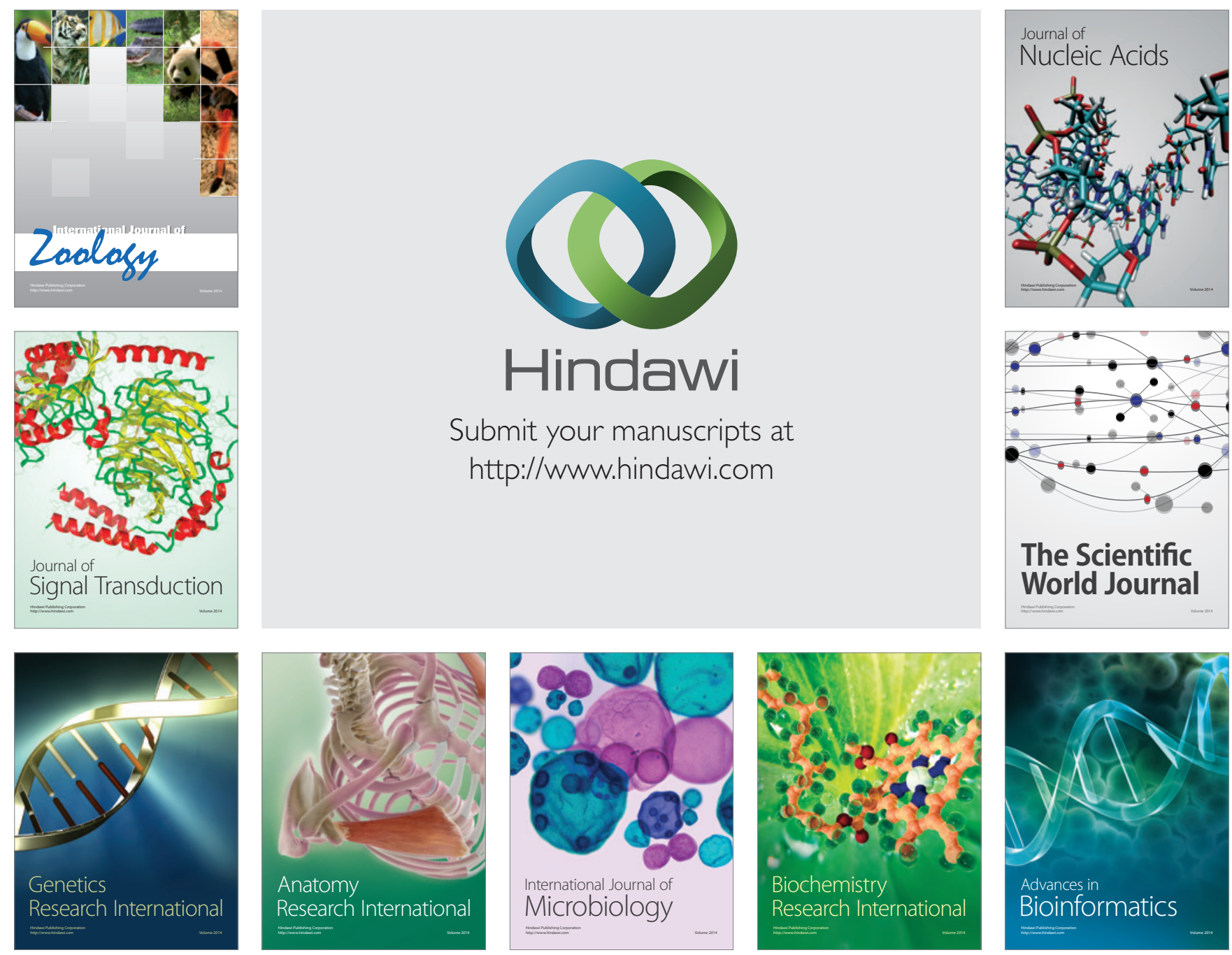

The Scientific World Journal
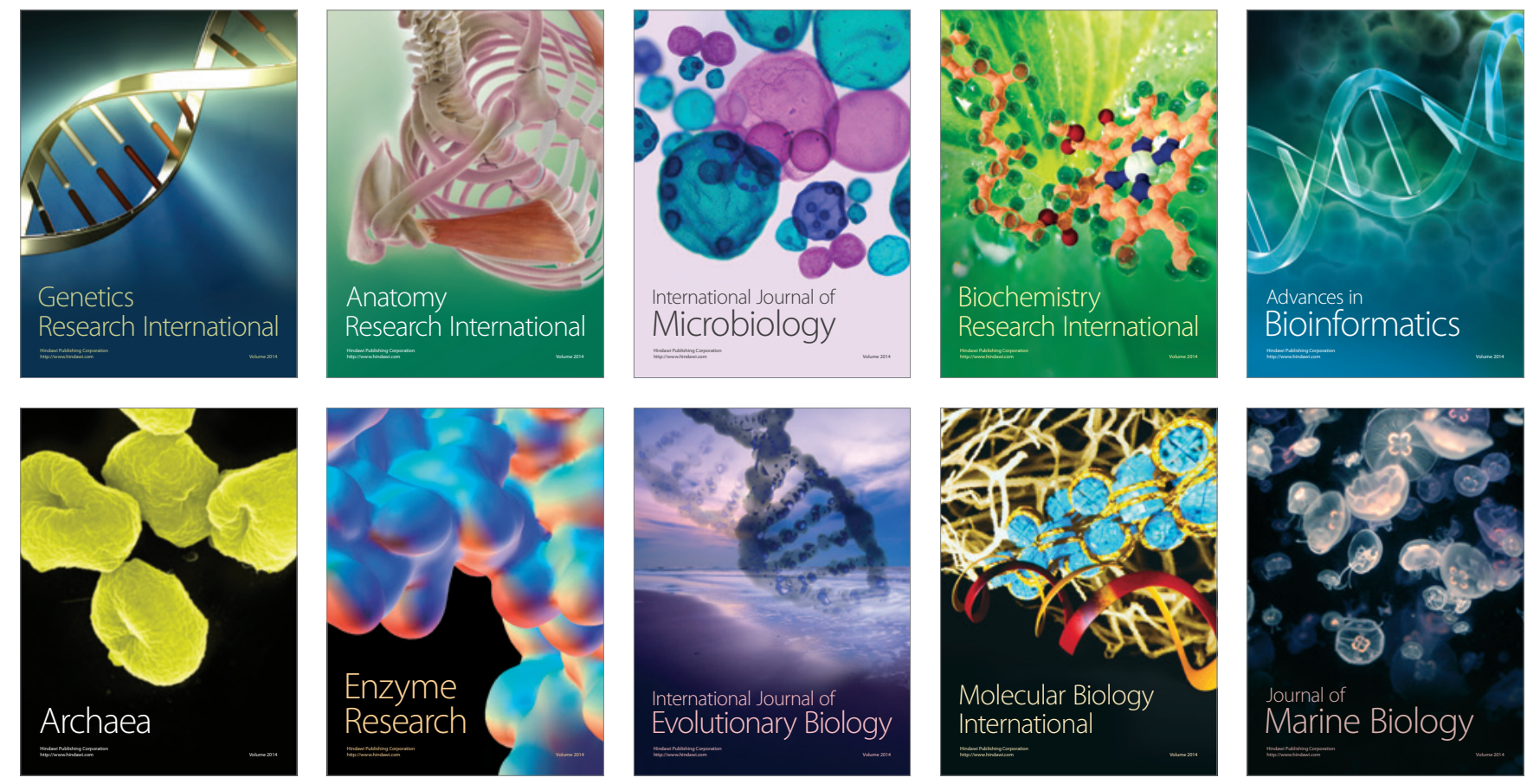